\title{
Bir Olgu Sunumu: Hipersensitivite Pnömonisi
}

\section{A Case Report: Hypersensitivity Pneumonia}

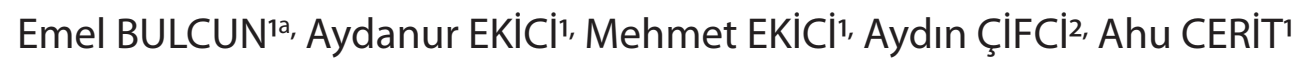

\author{
${ }^{1}$ Kırıkkale Üniversitesi Tıp Fakültesi, Göğüs Hastalıkları Anabilim Dalı, \\ ${ }^{2}$ Kırıkkale Üniversitesi Tıp Fakültesi, İç Hastalıkları Anabilim Dalı, Kırıkkale, TÜRKiYE
}

\section{öz}

Nefes darlığı, öksürük semptomları ile gelen PA akciğer grafisi doğal olan ancak detaylı anamnezle güvercin maruziyeti öyküsü tarifleyen ve hipersensitivite pnömonisi tanısı alan olguyu sunduk. 66 yaşında erkek hasta üç aydır olan nefes darlığı, öksürük şikayetleri ile polikliniğine başvurdu. Fizik muayenesinde solunum sesleri doğaldı. Çevresel, mesleksel maruziyet ve özellikli bir ilaç kullanım öyküsü yoktu. PA akciğer grafisi normaldi. Toraks yüksek çözünürlüklü bilgisayarlı tomografi (YÇBT)'de orta ve alt loblarda daha belirgin olan yaygın buzlu cam dansitesinde sentriasiner nodüller izlendi. Hastanın evin çatısındaki güvercinlere ait atık ürünlerini haftalık temizlediği öğrenilmesi üzerine güvercinlerle direk ve dolaylı maruziyetinin kesilmesi önerildi. Bir ay sonraki kontrolünde öksürük ve nefes darlığı semptomlarında gerileme olduğu öğrenildi. Kontrol toraks YÇBT'de her iki akciğerde izlenen yaygın sentriasiner nodüllerin kaybolduğu görüldü. Nefes darlığı, öksürük gibi semptomlarla başvuran hastalarda akciğer grafisi normal bile olsa hipersensitivite pnömonisinin de olabileceği göz önünde bulundurulmalı ve hastaların maruziyet öyküsü detaylı olarak sorgulanmalıdır.

Anahtar kelimeler: Hipersensitivite pnömonisi, sentriasiner nodüller, tomografi

\section{ABSTRACT}

A case of hypersensitivity pneumonitis with symptoms of dyspnea and cough, with normal PA chest radiography and with the anamnesis of pigeon exposure was presented here. 66 years old male patient had complaints of dyspnea and cough since 3 months. His respiratory sounds were normal. He did not have other environmental, occupational or drug exposure history. In thorax high resolution computed tomography (HRCT), there were centriacinar nodules in the middle and lower lobes. When his anamnesis was reevaluated, we learned that he was cleaning up pigeon droppings from roof every week. The patient was instructed to stop having direct and indirect contact with pigeons. One month after, the patient was reevaluated. His cough and dyspnea were improved. In his followup thorax HRCT, centriacinar nodules were disappeared. We should always consider hypersensitivity pneumonitis in the patients with the complaints of dyspnea, cough, even if the PA radiography is normal; we should take the exposure history comprehensively.

Key words: Hypersensitivity pneumonia, centriacinar nodules, tomography

Sorumlu Yazar a : Dr. Emel BULCUN, Kırıkkale Üniversitesi Tıp Fakültesi, Göğüs Hastalıkları Anabilim Dalı, 71100, Kırıkkale, TURKEY

Phone: 00903183335000 e-mail: emelbulcun@hotmail.com

Received: 30.07.2015 Accepted: 01.12.2015

doi: $10.18663 /$ tjcl.56226 


\section{Giriş}

Hipersensitivite pnömonisi (HP), antijenik ajanların yoğun ve tekrarlayan inhalasyonları sonucu gelişen, interstisyel ve parankimal dokuları etkileyen inflamatuar bir hastalıktır [1]. Seyrek görülmesi ve tipik bir semptomu olmaması nedeniyle gözden kaçabilmektedir. Biz burada nefes darlığı, öksürük semptomları ile gelen PA (postero-anterior) akciğer grafisi doğal olan ancak detaylı anamnezle güvercin maruziyeti öyküsü tarifleyen ve HP tanısı alan olguyu sunduk.

\section{Olgu Sunumu}

66 yaşında erkek hasta. 3 aydır olan nefes darlığı, öksürük şikayetleri ile Göğüs Hastalıkları polikliniğine geldi. Fizik muayenesinde solunum sesleri doğaldı ve ek ses yoktu. 30 paket/yıl sigara öyküsü olup 3 yıldır sigarayı bırakmıştı. Çevresel, mesleksel maruziyet ve özellikli bir ilaç kullanım öyküsü yoktu. PA akciğer grafisinde normal radyolojik bulgular izlendi. Parmak ucundan saturasyon O2 değeri \%96-98 ve nabzı 92/dk. idi. Solunum fonksiyon testi (SFT)'nde FEV1: 3.57 (\%123), FVC: 4.35 (\%117), FEV1/ FVC: 82 , DLCO: 34,99 (\%138) DLCO/VA: 4,98 (\%128) TLC: 6,80 (\%105) RV/TLC: 79 idi. Biyokimyasında, CRP: 3mg/L, BK: 6.3×103/ $\mathrm{uL}$, olup diğer değerler de normal sınırlardaydı. Hastaya toraks yüksek çözünürlüklü bilgisayarlı tomografi (YÇBT) tetkiki istendi. Orta ve alt loblarda daha belirgin olan yaygın buzlu cam dansitesinde sentriasiner nodüller izlendi (Resim 1). Hastanın anamnezi tekrar detaylı olarak sorgulandığında evin çatısındaki güvercine ait atık ürünlerini haftalık temizlediği öğrenildi. Hastaya güvercinlerle direk ve dolaylı maruziyetinin kesilmesi önerildi. İnhaler budesonid $400 \mathrm{mcg}$ +formeterol $12 \mathrm{mcg} 2 \times 1$ başlandı. Hasta bir ay sonra tekrar değerlendirildi. Öksürük ve nefes darlığı semptomlarında gerileme vardı. SFT değerleri FEV1: 3,68 (\%127), FVC: 4,44 (\%119), FEV1/FVC: 79,5 ve DLCO: 37,40 (\%147) DLCO/VA: 5,44 (\%139) TLC: 6,92 (\%106) RV/TLC: 61,3 şeklindeydi. Çekilen kontrol toraks YÇBT'de her iki akciğerde izlenen yaygın sentriasiner nodüllerin kaybolduğu görüldü (Resim 2).

\section{Tartışma}

HP veya ekstrensek alerjik alveolit çeşitli organik partiküllere tekrarlayan maruziyet sonrası duyarlı kişilerde akciğer parankiminde ve küçük hava yollarında immunolojik ilişkili inflamasyon yapan çeşitli organik partiküllere tekrarlayan maruziyet sonrası ortaya çıkan heterojen bir grup hastalıktır [1]. Hastalıktan sorumlu olan antijenler kuş ve memeli hayvan proteinleri, çeşitli funguslar, bakteriler, izosiyanat, trimellitik anhidrat, sodyum dibenzen sülfat, pitalik anhidrat gibi bazı küçük kimyasal moleküllerdir [2]. Başlangıçtaki spesifik olmayan enflamasyondan sonra duyarlılık ve genetik olarak kontrol edilen granülomatöz enflamatuar cevap sonucu ortaya çıktığı ileri sürülmüştür [3].

Birçok kişi gerek mesleki gerekse ev ortamında sorunlu antijenlere maruz kalmaktadır. Ancak fazla sayıda bireyin HP ile ilişkili antijenlerle temas etmesine rağmen hastalığın prevalansı ve insidansı göreceli olarak düşüktür. Bunun iki nedeni olabileceği düşünülmektedir. Birincisi hastalığın fark edilememesi ve tanı konulamaması olduğu, ikincisi ise diğer çevresel ve genetik birtakım kolaylaştırıcı faktörlerin hastalığın gelişimini tetiklediği ileri sürülmüştür [4].

Viral enfeksiyonlar HP gelişimini tetikleyebilir. Buradaki muhtemel mekanizma, virüs ilişkili mukosilier disfonksiyon, alveolar makrofajlardan hastalığın gelişimini tetikleyici birtakım sitokinlerin artışı ve viral enfeksiyonların akciğerlerde lenfositik infla- masyon yanıtını artırması olabilir [5]. Tarımda kullanılan özellikle organoklorin ve karbamat pestisit gibi bazı pestisitlere maruz kalmanın da HP'nin bir alt grubu olan çiftçi akciğeri gelişimini tetiklediği görülmüştür [6].

Kuş besleyenlerde görülen hipersensitivite reaksiyonu HP'lerinin bir alt grubudur. Kuşa ait organik partiküllerin tekrarlayan solunumu sonucu akciğerde parankim harabiyeti oluşur. Düşük doz maruziyet ve indirekt karşılaşanlardaki insidansı bilinmemektedir. Kuşa ait yoğun antijenle karşılaşanlar arasında HP prevalansının \%5-15 arasında olduğu bildirilmiştir [7]. Hastalığın şiddeti, kuşlardan salınan antijenlere maruziyetin süresiyle orantılıdır. Güvercinler HP oluşumuna neden olan en sık kuş türü olarak bilinse de benzer hastalık papağan, muhabbet kuşu, hindi ve tavuk proteinleriyle de oluşabilmektedir [8].

HP maruz kalınan organik partiküllerin özelliğine, yoğunluğuna ve antijen temasının sıklığına göre akut, subakut ve kronik olmak üzere 3 faklı klinik formda karşımıza çıkar [4]. Akut HP antijen maruziyetinden sonra saatler içerisinde meydana gelen grip benzeri sendromla karakterizedir. Semptomlar maruziyet kesildikten sonra aşamalı olarak azalır ve tekrar antijen teması ile ortaya çıkar. Akut HP epizodunu viral veya mikoplazma gibi etkenlere bağlı respiratuar enfeksiyonlardan ayırt etmek zordur [9]. Akut formda kuru vasıfta öksürük ve nefes darlığı gibi semptomlarla birlikte ateş, üşüme, titreme ve miyalji gibi sistemik semptomlar da görülebilir. Subakut HP tekrarlayan düşük düzey inhaler antijen maruziyeti sonrası haftalar veya birkaç ay içerisinde görülür. Nefes darlığı, öksürük, yorgunluk gibi semptomlarla karakterizedir. Bu formda genellikle nefes darlığı ve öksürük progresif olarak devam eder.

Olgumuzun 3 aydır olan nefes darlığı, öksürük şikayetleri mevcuttu. Bu şikayetleri nedeniyle olgumuz daha çok subakut HP formuna uymaktaydı. Tanı konulmamış akut ve subakut form kronik forma doğru ilerler. Bu klinik form özellikle kuş antijenlerine maruz kalanlarda sık rastlanır [10]. Klinik ilerleyici nefes darığı, öksürük, yorgunluk, kilo kaybı ile karakterizedir. Sıklıkla bu hastalarda progresif fibrozis görülür ve ilerlemiş formu idipatik pulmoner fibrozise ve fibrotik nonspesifik interstisyel pnömoniye benzer [11].

Akut ve subakut formda akciğer grafisi genellikle normaldir. Toraks YÇBT HP'nin klinik formlarını ayırmada oldukça kullanışlıdır. Semptomatik akut HP'li hastalarda normal olabilir [12]. Anormal olduğu zaman buzlu cam alanları veya kötü sınırlı küçük nodüller olabilir. Yine subakut HP'de buzlu cam alanları ve kötü sınırlı küçük nodüller sıktır. Mozaik atenüasyon paterni de izlenebilir [13]. Bizim olgumuzun toraks YÇBT'de her iki akciğerde yaygın sentriasiner nodüler görünümleri vardı. Bu görünümleri ile akutsubakut HP radyolojisine benzer görünüm izlendi. Kronik HP'nin YÇBT bulguları da retiküler görünümler, interlobüler septal kalınlaşmalar, traksiyon bronşektazileri ve bal peteği görünümlerini içerir. Sigara içen kronik HP olgularında amfizematöz görünümler de gelişebilir [14]. Kronik HP'nin YÇBT bulguları idyopatik pulmoner fibrozis (IPF)'e benzer. Ancak mozaik atenüasyon, sentrilobüler nodüler görünümlerin olması ve alt zon dominansının görülmemesi IPF'den ayırt edici özellikleridir [15].

HP'de akciğer fonksiyon testleri diğer interstisyel akciğer hastalıkları ile benzer özellikler taşıdığından spesifik veya tanısal değildir. İlerlemiş olgularda FVC ve total akciğer kapasitesindeki azalmayla karakterize restriktif ventilatuar anormallikleri ve kısıtlanmış kompliansla birlikte DLCO azalması görülür [10]. Akut 
HP'de akciğer fonksiyonları normal olabilir [12]. Hipoksemi yaygındır ancak hafif-orta şiddetteki hastalarda dinlenme sırasında normoksemik olabilir egzersiz ile hipoksemi ortaya çıkabilir [10]. Olgumuzda parmak ucunda saturasyon değerine göre hipoksemi görülmedi. Yine, olgumuzun SFT'lerinde FVT, TLC ve DLCO değerleri düşük değildi. Ancak olgumuzun güvercin maruziyeti kesildikten 2 ay sonraki FVT, TLC ve DLCO değerleri ilk değerleri göre hafif artış gösterdi.

HP diğer intertisyel akciğer hastalıklarından ayırt edilemeyebilir bu nedenle tanısında zorluklar yaşanır. HP tanısı yüksek klinik şüpheye, antijen maruziyet öyküsüne, klinik, radyolojik, laboratuar ve patolojik bulguların kombinasyonuna bağlıdır [16]. Eğer akciğer biopsisi yapılırsa granulamatöz interstisyel bronkosentrik pnömonitis görülür [17]. Kuş besleyicisi hastalığında spesifik bronş provakasyon testi, serum ve BAL'da spesifik antikorların varlığı, BAL CD4/CD8 oranının düşük olması ve transbronşial biopsi tanıya katkı sağlamaktadır ancak pratik uygulamada çok gerekli olmadığı bildirilmektedir. Maruziyet ajanının belirlenmesi ve sorumlu etkenden uzaklaşmakla kliniğin düzelmesinin en iyi tanı kriteri olabileceği söylenmektedir [18]. Olgumuzda maruz kalınan etkenden uzaklaşma ile düzelme sağlanması nedeniyle hastane koşullarımızda sağlanamadığından spesifik antikor testinin dış merkezde yapılmasında ısrar edilmemiştir. Yine olgumuz bronkoskopi işlemini kabul etmemesi nedeniyle bronkoskopi yapılamamıştır. Hastanın semptomları, güvercinle temas öyküsü ve tipik toraks YÇBT bulguları ve güvercinle maruziyetinin kesilmesi ile semptomların kaybolması, radyolojik bulguların düzelmesi hastada güvercin temasına bağlı HP pnömonisi tanısı koymamıza olanak sağladı.

Tedavinin en önemli bileşeni erken tanı ve antijen maruziyetinin en kısa sürede kesilmesidir. Antijen temasının kesilmesi ekonomik ve sosyal nedenlerden dolayı her zaman mümkün olamamaktadır. Böyle durumlarda hem ev hem de mesleki ortamda koruyucu önlemlerin alınması gerekir [19]. Tedavide hastanın etkenden uzaklaştırılması çoğu olguda yeterli olmaktadır. Nitekim bizim olgumuzda da güvercin temasının kesilmesi ile yeterli tedavi sağlanmıştır. Subakut olgularda antijen maruziyetinden kaçınma ile birlikte 3-6 ay prednizolon verilebilir. Ancak subakut progresif ve kronik olgularda daha uzun süreli steroid kullanımına ihtiyaç olabilir. Prednizolon genel olarak $0,5 \mathrm{mg} / \mathrm{kg} / \mathrm{gün}$ dozunda başlanıp 4-6 hafta sonra doz kademeli olarak yaklaşık $10 \mathrm{mg} /$ gün dozuna erişinceye kadar azaltılır ve bu dozda devam edilir [20]. Klinik ve fonksiyonel yanıtsızlıkta steroid tedavisinin kesilmesi önerilir. Akciğerde fibrotik hastalıkla karakterize kronik progresif ilerlemiş HP'de etkili tedavi yoktur akciğer transplantasyonu önerilir [10].

Sonuç olarak öksürük ve nefes darlığı gibi semptomlarla gelen hastaların PA akciğer grafileri normal olsa bile HP açısından ayrıntılı anamnezleri alınmalıdır. Çünkü olguların akut, subakut dönemlerinde grafileri normal veya şüpheli olabilir. Bizim olgumuzda da ilk gelişinde PA akciğer grafisi normal idi. Çekilen toraks YÇBT'de yaygın sentriasiner nodüllerinin olması nedeniyle hastanın anamnezi tekrar HP açısından detaylı şekilde sorgulandığında aralıklı olarak güvercine ait atıkları temizlediğini belirtmesi üzerine hastada HP tanısı düşünüldü ve etkenden uzaklaştırılarak tedavi edildi.

\section{Çıkar çatışması ve Finansman Beyanı}

Bu çalışmada çıkar çatışması ve finansman destek alındığı beyan edilmemiştir.

\section{Kaynaklar}

1. Bojko T, Notterman DA, Greenwald BM, De Bruin WJ, Magid MS, Godwin T. Acute hypoxemic respiratory failure in children following bone marrow transplantation: an outcome and pathologic study. Crit Care Med 1995; 23: 755-9.

2. Griffiths $M H$, Miller RF, Semple SJ. Interstitial pneumonitis in patients infected with the human immunodeficiency virus. Thorax 1995; 50: 1141-6.

3. Salvaggio JE. Immune reactions in allergic alveolitis. J Eur Respir 1991; 4: 47-59.

4. Selman M. Hypersensitivity pneumonitis: a multifaceted deceiving disorder. Clin Chest Med 2004; 25: 531-47.

5. Dakhama A, Hegele RG, Laflamme G, Israël-Assayag E, Cormier Y. Common respiratory viruses in lower airways of patients with acute hypersensitivity pneumonitis. Am J Respir Crit Care Med 1999; 159:1316-22.

6. Hoppin JA, Umbach DM, Kullman GJ, et al. Pesticides and other agricultural factors associated with self-reported farmer's lung among farm residents in the Agricultural Health Study. Occup Environ Med 2007; 64: 334-341.

7. Selman M, Chapela R, Raghu G. Hypersensitivity pneumonitis: Clinical manifestations, pathogenesis, diagnosis, and therapeutic strategies. Semin Respir Med 1993; 14: 353-64.

8. Morell F, Roger A, Reyes L, Cruz MJ, Murio C, Muñoz X. Birdfancier's lung: a series of 86 patients. Medicine (Baltimore) 2008; 87: 110-30.

9. Chryssanthopoulos C, Fink JN. Clinical-immunologic correlates: a differential diagnostic update. Hypersensitivity pneumonitis. J Asthma 1983; 20: 285-296.

10. Selman M, Pardo A, King TE. Concise Clinical Review Hypersensitivity Pneumonitis Insights in Diagnosis and Pathobiology. Am J Respir Crit Care Med 2012; 186: 314-24.

11. Churg A, Muller NL, Flint J, Wright JL. Chronic hypersensitivity pneumonitis. Am J Surg Pathol 2006; 30: 201-8.

12. Lynch DA, Rose CS, Way D, King TE Jr. Hypersensitivity pneumonitis: sensitivity of high-resolution CT in a population-based study. AJR Am J Roentgenol 1992; 159: 469-72.

13. Patel RA, Sellami D, Gotway MB, Golden JA, Webb WR. Hypersensitivity pneumonitis: patterns on high-resolution CT. J Comput Assist Tomogr 2000; 24: 965-70.

14. Akashi T, Takemura T, Ando N, et al. Histopathologic analysis of sixteen autopsy cases of chronic hypersensitivity pneumonitis and comparison with idiopathic pulmonary fibrosis/usual interstitial pneumonia. Am J Clin Pathol 2009; 131: 405-5.

15. Silva Cl, Muller NL, Lynch DA, et al. Chronic hypersensitivity pneumonitis: differentiation from idiopathic pulmonary fibrosis and nonspecific interstitial pneumonia by using thin-section CT. Radiology 2008; 246 : 288-97.

16. Selman M, Buendía RI. Immunopathology, diagnosis, and management of hypersensitivity pneumonitis. Semin Respir Crit Care Med 2012; 33: 543-54.

17. Churg A, Sin DD, Everett D, Brown K, Cool C. Pathologic patterns and survival in chronic hypersensitivity pneumonitis. Am J Surg Pathol 2009; 33: 1765-70.

18. Gayaf M, Karasu I, Çakan A, Özsöz A, Aydoğdu Z. Güvercin Besleyici Hastaı̆̆ı (Hipersensitivite Pnömonisi) Pigeon Breeder's Disease (Hypersensitivity Pneumonitis). Solunum Dergisi Solunum 2010; 12: 47-51.

19. Kurup VP, Zacharisen MC, Fink JN. Hypersensitivity pneumonitis. Indian J Chest Dis Allied Sci 2006; 48: 115-28.

20. Selman M. Hypersensitivity pneumonitis. In: Interstitial lung disease, 5th ed. Schwarz M, and King TE Jr, editors. Shelton, CT: People's Medical Publishing House-USA; 2011. pp. 597-625. 